\section{Multidisciplinary \\ SCIENTIFIC JOURNAL OF \\ MARITIME RESEARCH}

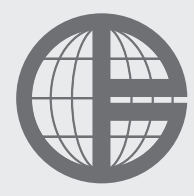

University of Rijeka

Faculty of Maritime

Studies Rijeka

\section{Multidisciplinarni \\ znanstveni časopis \\ POMORSTVO}

\title{
Beaches destination management - case study Penninsula Pelješac
}

\author{
Daniela Gračan, Zrinka Zadel, Željka Vlahušić \\ University of Rijeka, Faculty of Tourism and Hospitality Management Opatija, Primorska 42, p.p. 97, 51410 Opatija, Croatia, e-mail: danielag@fthm.hr
}

\section{ABSTRACT}

Tourism destination is a complicated system. Destination system consists of resources which can be natural and anthropogenic. It is necessary to harmonize them and to manage them in proper manner. Coastal area is one of the most valuable natural resources od Republic of Croatia which is well known and recognized as sun, sea\&sand destination, and therefore coastal area is crucial for tourism development. Beaches, as part of coastal area, are foundation of competitive advantage, as well as income generator and due to this, there is growing interest in last couple years for possibility of using their recreational and economic potential.

Purpose of this paper is, by using quantitative and qualitative analysis, to research beach resources of Pelješac peninsula which will then be used as a foundation for SWOT matrix to determine strengths, weaknesses, opportunities and threats to beaches of this area. For the analysis purpose, beside the secondary data research, there was a field research conducted which covered attitudes of key stakeholders and tourism board management of Pelješac peninsula which together make destination management of beach resources.

\section{ARTICLE INFO}

\section{Review article}

Received 16 May 2016

Accepted 13 June 2016

\section{Key words:}

Beaches

Beach management

Destination management

Beaches destination management

\section{Introduction}

Tourism in a specific area could not prosper without the attractions which ensure that thi certain place is a destination. In order for an area to be called a tourist destination or destination zone, it must meet various criteria: ${ }^{1}$

- The area must have a certain number of cultural, physical and social characteristics that ensure a specific/distinctive identity;

- The area must be equipped with adequate infrastructure (transport communications, utilities, supporting the service industry and other industries indispensable for tourists and businesses in the tourism sector);

- Area of tourist destination zone should cover an area much larger than just one attraction or a local community;

- The destination zone must include a full range of attractions and to be able to create new products to attract tourists;

- Tourist Destination zone must have a development office, i.e. Public office which will support and guide

1 Gunn, C., Tourism Planning, Taylor and Francis, London, New York, 1988, p. 54. the local entrepreneurs and companies in their development activities;

- Destination zone area should be reachable to a larger number of tourists (by road, air or sea).

Without quality management, destination can not compete at market for a long term. It is dynamic and changes in tourism demand are happening very quickly. When it comes to tourist organization as a system, it must, with appropriate structure, be able to respond to certain challenges, and that is that management must ensure the survival tourism organizations. As a non-profit organization it must initiate various activities, efficient "production" of holiday offer that is for its members in destination meaningful and desirable. This is only possible if successfully maintained the competitive ability of destination. ${ }^{2}$

A modern tourist environment requires high-quality management of tourist destinations, conducted by destination management organizations. Destination Management is a result of the inclusion of different sectors, groups of stakeholders and partners - such as government agencies, local communities, business clubs and associations

2 Magaš, D.: Management turističke organizacije i destinacije, Sveučilište u Rijeci, Fakultet za turistički i hotelski menadžment u Opatiji, Adamić, Rijeka, 2003., p. 75. 
- working together, each from their own perspective, to realize common goals of specific destination. During destination management, it is important to recognize and manage the unique natural resources, cultural attributes and interests of the community of each individual destination. Tourism should allow the achievement of positive effects today, but also should create a perspective for future generations (the principle of sustainable development). ${ }^{3}$ Therefore, the destination management should be seen as tourism activities that engage local interests within purposeful business relationship with offer carriers, in order to create a destination product. ${ }^{4}$

The fundamental purpose of destination development is to ensure compliance of tourism development process in such a way to align management processes of tourism and tourism related activities, by continuous cooperation and partnership between the public and private sectors. ${ }^{5}$

The beaches in Croatia are the basic resource upon which the tourism product is built. The management of beaches is entrusted, by Croatian law, to regional and local self-government. The forms of commercial exploitation of beaches in Croatia are based on legal solutions that involve the granting of concessions or concession licenses. While getting the concession licenses follows a simple procedure, the procedure for granting concessions is complicated and time consuming. The frequent changes in laws and regulations lead to legal uncertainty which in the future should definitely be avoided and procedures should be simplified. ${ }^{6}$ In this way, management of beaches has the function of retaining or improving the beach as a recreational resource, as an instrument to protect the coast, and a very important function of beaches management. In this context, good governance of beaches would be a continuous process that will ensure the protection of beaches as a resource, as well as maintainace of the beach, within the available resources (financial).

The term beaches means a complex system uniting land and sea, an extremely valuable natural habitat and significant area with which the specific social and economic circumstances are linked. ${ }^{7}$ Authord Williams and Micaleff ${ }^{8}$ define a beach as a cluster of unconsolidated material (eg.

\footnotetext{
3 Operativni priručnik za primjenu modela destinacijske menadžment organizacije (DMO), Glavni ured Hrvatske turističke zajednice, Horwath HTL Zagreb, 2013. http://business.croatia.hr/Documents/3217/Operativni-prirucnik-za-primjenu-modela-destinacijske-menadzment-organizacije.pdf.

4 Magaš, D.: Destinacijski menadžment - modeli i tehnike, FTHM Opatija, 2008, p. 2.

5 Cetinski, V.: Strateško upravljanje razvojem turizma i organizacijska dinamika, FTHM Opatija, 2005., p. 50-51.

6 Pilot projekt "1.000 hrvatskih plaža - Jadranske morske zvijezde Kvarnera", Fakulteta za menadžment u turizmu i ugostiteljstvu, Opatija, 2013, p. 3.

7 Simm, J. D., Beech, N. W., John, S.: A Manual for Beach Management, Proceedings of Conference in Costal Management '95, Putting Policy into Practice, Institution of Civil Engineers, Bournemouth, Thomas Telford, UK, 1995, p. 143-162.

8 Williams, A.; Micaleff, A.: Beach Management: Principle\&PracticeEart hcanPublicationsLtd., London, UK, 2009, p. 10.
}

sand, gravel, clay or mixtures thereof), extending from the land edge of beach, which can be slopes of dunes or seawall, to the depths of the sea, where there is no significant movement of sediment. Classification of beaches in Croatia is based on multiple legal solutions. According to the Ordinance on the types of beaches and conditions to be met ${ }^{9}$, beach are divided into arranged and natural beaches. According to the Regulations, arranged beach is onshore area directly connected with the sea, furnished with sanitary facilities, showers and cabins, surrounded by the sea, which is accessible to all on equal terms. Natural beach is undeveloped and with the sea directly connected onshore area that is accessible to everyone.

In accordance with the Tourism Development Strategy of Croatia by 2020, The Ministry of Tourism has prepared a National Programme of Planning and beach management $^{10}$. Croatian beaches, with their beauty, are an asset to be protected and used wisely, because once destroyed are difficult or impossible to repair. Therefore, the scientists and experts have to recognize their role and do their best to preserve this highly valuable resource for future generations.

The beaches are an integral part of an integrated tourist product of a destination. This is a highly valuable resource in terms of natural, social, economic and recreational potential. They make the tourism product attractive and represent motive for arrival in a destination for a number of tourists. ${ }^{11}$ In order to put the beaches into place of tourist attractions and positioning of a tourist destination on the tourism market, and to make a tourism product of destination more attractive it is necessary to enrich the offer of beaches according to the wishes of market segments with respect to the principles of sustainable development.

\section{Pelješac penninsula beaches area analysis}

On the Pelješac peninsula, there are beach-resources which are not fully utilized. All from the municipality of Ston on the beginning of peninsula, and to Orebić, as the peninsula is divided; many places are rich with beach areas. They are managed mainly by responsible municipalities, and the Table 1 shows beaches in the municipalities of the Pelješac peninsula.

The beaches that are most often recognized by tourists visitors are beaches in the bay of Žuljana (municipality Ston), beach Trstenica (Orebić), beaches in the bay Prapratno (municipality Ston), beaches in Viganj (municipality Orebić) for lovers of surfing and beach Divna (municipality Trpanj). Due to mechanical and chemical effects

\footnotetext{
9 Pravilnik o vrstama morskih plaža i uvjetima koje moraju zadovoljavati, NN 50/95.

10 Nacionalni program upravljanja i uređenja morskih plaža - Akcijski plan, Ministarstvo turizma, prosinac 2014.

11 Regionalni program uređenja i upravljanja morskim plažama na području Primorsko-goranske županije, Primorsko-goranska županija, 2015, p. 7.
} 
Table 1 Local beaches by municipalities

\begin{tabular}{|l|l|}
\hline \multicolumn{1}{|c|}{ Municipality name } & \multicolumn{1}{|c|}{ Name of the town with beach } \\
\hline Ston & $\begin{array}{l}\text { Broce, Stonska Duba, Hodilje, Luka, Prapratno, Kobaš, Marčuleti, Brijesta, Vučine, Grdni Do, Pržina, Kremena 1, Kremena 2, } \\
\text { Kupljenova, Luka Dubrava }\end{array}$ \\
\hline Janjina & Drače, Sreser, Bililo, Bratkovice, Sutvid \\
\hline Trpanj & Duba, Divna, Pozora \\
\hline Orebić & Trstenica, Mokalo, Lovište, Viganj, Kučište, Podobuće, Dingač, Trstenik \\
\hline
\end{tabular}

Source: Authors

Table 2 Beaches characteristics

\begin{tabular}{|c|c|c|c|}
\hline Beach name & Beach type & Sort of beach & Content \\
\hline Broce & Natural & Pabbly & I \\
\hline Stonska Duba & Natural & Pebbly & / \\
\hline Hodilje & Natural & Pebbly & I \\
\hline Prapratno & Arranged & Sandy & Cabins, deck chairs, shower, paddleboats \\
\hline Marčuleti & Natural & Sandy & / \\
\hline Kučište & Natural & Pebbly & I \\
\hline Vučine & Natural & Pebbly & Shower \\
\hline Kremena I & Natural & Pebbly & / \\
\hline Kremena Ii & Natural & Pebbly & / \\
\hline Grdni do & Natural & Pebbly & I \\
\hline Trstenik & Natural & Pebbly & I \\
\hline Zamali & Natural & Pebbly & / \\
\hline Zaglavak & Natural & Pebbly & I \\
\hline Dranče & Natural & Pebbly & 1 \\
\hline Pozora & Natural & Pebbly & 20 deck chairs, 2 showers, parasols, kayaks \\
\hline Divna & Natural & Sandy/Pebbly & / \\
\hline Duba & Natural & Pebbly & / \\
\hline Vrila & Natural & Pebbly & 1 shower \\
\hline Uvala Jezero & Natural & Sandy/Pebbly & I \\
\hline Luka & Natural & Pebbly & 2 showers, beach fence \\
\hline
\end{tabular}

Source: Processing of the author according to the data obtained by interviewing stakeholders of Tourist Board of the Pelješac peninsula.

of sea water on the limestone coast, numerous bays and coves with sandy and pebble beaches have been formed. Steep coastal sections in this part of Pelješac coast were created by tectonic movements, i.e., vertical uplift of coast, and therefore southwest coast is more attractive, but also less accessible and harder for tourist valorization. The Table 2 analyzes the beach resources in terms of type, kind and content of a particular beach.

Pelješac Peninsula is industrially undeveloped, so there are no potential polluters of the sea and nature. The sea is clean, and the coastal belt of the peninsula is enough indented and rich in small bays where a variety of beaches can be found: sandy, rocky or gravelly. ${ }^{12}$

The Table 3 shows the key characteristics of the beaches as well as initiatives that are necessary for the development of beach space in this area.

\footnotetext{
12 http://www.orebic-peljesac.eu/hr/txt_plaze-na-peljescu-i-u-orebicu. html, (14.05.2014.).
} 
Table 3 Characteristics and initiatives for beaches

\begin{tabular}{|c|c|}
\hline & Sun and sea \\
\hline Key characterictics & $\begin{array}{l}\text { - The beauty of natural beaches and bays (Prapratno, Kobaš, Stonska Duba, Brijesta, Trstenica, etc.) } \\
\text { - Activities for different segments (families with children, DINKS, etc.) } \\
\text { - Numerous excursion possibilities } \\
\text { - Recreational water activities (Viganj) } \\
\text { - Recreation in high-grade natural setting }\end{array}$ \\
\hline $\begin{array}{l}\text { Key initiatives for } \\
\text { development }\end{array}$ & $\begin{array}{l}\text { - Project of Development and Planning of beach areas } \\
\text { - Rehabilitation of existing (Orebić) and new projects of tourist accommodation } \\
\text { - The offer of recreational activities and water sports } \\
\text { - Additional professionalisation and further development of water activities } \\
\text { - The organization of various recreational activities and offers of special interest (product development) }\end{array}$ \\
\hline
\end{tabular}

Source: Processing of the author according to the spatial plan of Ston.

Table 4 Penninsula Pelješac beaches area SWOT matrix

\begin{tabular}{|c|c|}
\hline Strenghts & Weaknesses \\
\hline $\begin{array}{l}\text { - Sea and beaches qualites } \\
\text { - Comparative advantages } \\
\text { - The beauty, diversity and preservation of the landscape } \\
\text { - A larger number of protected natural sites (Mali Ston Bay and Malo } \\
\text { more, Prapratno and Vučina etc.) } \\
\text { - The low level of pollution (air, sea, no noise) } \\
\text { - The positive attitude of the local population towards tourism } \\
\text { - Institutionalized role of municipal TB in tourist promotion of } \\
\text { Pelješac } \\
\text { - Good collaboration of TBs on the level of Pelješac } \\
\text { - Regular presence at tourist fairs } \\
\text { - Availability of promotional materials }\end{array}$ & $\begin{array}{l}\text { - Not Adequate valorization of natural resources for tourism purposes } \\
\text { - Lack of newly tourist attractions } \\
\text { - Badly equipped tourist development zones with infrastructure systems } \\
\text { - Overwhelming dependence on seasonal beach tourism } \\
\text { - Lack of the organizers of special activities } \\
\text { - The lack of interest of international capital } \\
\text { - Lack of inter-municipal cooperation } \\
\text { - The lack of existence of a destination product in which there would be } \\
\text { embedded products of other selective forms of tourism } \\
\text { - An insufficient number of qualified individuals for management of tourism } \\
\text { development at the local level } \\
\text { - The lack of internationally trained tourism managers }\end{array}$ \\
\hline Opportunities & Threats \\
\hline $\begin{array}{l}\text { - Growing demand for ecologically preserved destinations } \\
\text { - Increased interest of the state for the development of the islands } \\
\text { - The availability of EU funds } \\
\text { - The growing interest of serious investors in the tourism sector } \\
\text { - Increased interest of small and medium-sized enterprises to invest } \\
\text { in various facilities / services related to tourism (integrated value } \\
\text { chain) } \\
\text { - Cooperation with other municipalities on the peninsula } \\
\text { - Growth and more pronounced segmentation of demand in the field } \\
\text { of so-called "special interests" }\end{array}$ & $\begin{array}{l}\text { - Inappropriately selected tourist development zones } \\
\text { - Disorganized and poorly designed process of tourism development } \\
\text { - The emphasis on "sun and sea" consumers } \\
\text { - The environmental degradation of space (sewage, garbage) } \\
\text { - Failure to satisfy the expectations of the tourist market } \\
\text { - Reducing the loyalty of existing guests } \\
\text { - Lack of cooperation between the public and private sector on development } \\
\text { projects in tourism } \\
\text { - Inadequate use of available development space } \\
\text { - Cheap destination image } \\
\text { - Orientation exclusively on the "sun and sea" guests }\end{array}$ \\
\hline
\end{tabular}

Source: Processing according to plan of tourism development of Pelješac.URL:http://www.visitorebic-croatia.hr/Content/dokumenti/65_plan\%20 razvoja\%20turizma\%20peljesca.pdf (20.03.2015.)

The most attractive bay and most suitable for tourist development is bay Prapratna which is the largest and in the immediate vicinity of Ston. At the western end of the peninsula, on the coast of the Korcula Channel, from cape Lovište to cape Hunting Osičac there is a large cove Luka, made up of several small attractive bays. Accessibility and placed position of that part of the Pelješac coast offers excellent conditions for tourist valorization. ${ }^{13}$

With pleasant Mediterranean climate, coastal area with numerous beaches is a key attraction of the Pelješac peninsula. In relation to its surface and quite small accommodation offer, the entire peninsula is considered ideal for an escape from the crowds and mass tourism, so the beaches of the Pelješac peninsula regularly stand out as romantic beaches of the Adriatic.

13 Glamuzina, N.: Pelješac, Naklada Bošković, Split, 2009., p. 60

\section{SWOT matrix of Pelješac peninsula beach area}

Based on the analysis of the main strengths and weaknesses, opportunities and threats of Pelješac peninsula beach area, sustainable tourism development is being supported, and seeks to maximize the use of the main strengths and opportunities and find the best solutions for the management of the main weaknesses of the beach areas. In so doing many dangers that could result from the previous use of beach of the Pelješac peninsula are taken into account.

The Table 4 shows the SWOT matrix of beach area of the Pelješac peninsula.

The diversity and beauty are the main features of untouched nature of the Pelješac peninsula. The air which is mixed scent of the sea and the Dalmatian medicinal herbs, unpolluted sea and Mediterranean vegetation represent a real vacation for all lovers of nature and ecology as well as for those who want to escape from the urban lifestyle. 
Another of the peculiarities of nature on the Pelješac peninsula refers to very various microclimatic areas. ${ }^{14}$ Pelješac peninsula is, due to climatic characteristics, very similar to the Dalmatian islands that surround it - Hvar, Korčula and Mljet. The fact is that it is connected to the mainland, but retains all the features of the island.

For this area rocky and sandy beaches with wonderful bays are typical. Fertile valleys are planted with olive trees, fig trees and vines. Pelješc Peninsula has a wide range of local dishes and local wines such as Dingač, Plavac, Postup and Pelješac. ${ }^{15}$

Beaches of Pelješac can be utilized in various tourist purposes. On it, in addition to sunbathing and swimming, a variety of activities such as recreation, workshops, diving and visiting the seabed, a tour of the surrounding vineyards and olive groves, and even a tasting of local specialties can be offered. Beach Trstenica in Orebiću is on the list of the most beautiful Croatian beaches. ${ }^{16}$ The beach Trstenica is located in Orebić, on the south side of the of Pelješac. The sandy beach Prapratno, located $3 \mathrm{~km}$ from Ston, is considered one of the most beautiful beaches on the Adriatic. The sea is warm and crystal clear and the beach is surrounded by bay with olive and pine trees. Near the beach is a summer camp that attracts hundreds of tourists. Prapratno, with recent building of the ferry port, has become important as a point of connection for the ferry from Prapratno to Mljet (Sobra). Somewhat inaccessible beach near Trpanj offers a tropical atmosphere on the peninsula. Along the coast of the "Great Sea" there is a series of pebble beaches in the endless bays along the coastline. The vast majority is accessible only by boat and is a great attraction for adventurers. ${ }^{17}$

In order fot peninsula to succeed in the market and eliminate its limitations, it is necessary to manage the overall tourism in a way that promotes itself as a destination that offers a high quality tourism product at any time of year.

\section{Research analyses}

For the purpose of scientific research paper, a sampling survey has been done among four Tourist boards because the tourist board is responsible for managing the development of tourism on the peninsula. The study surveyed a representative of each tourist board for the region/municipality (Ston, Janjina, Orebić and Trpanj) for which he responsible.

\footnotetext{
14 Southern Sun-Croatia, URL: http://www.southernsun-croatia.com/ cultureandnature/peljesac-nature.asp (19.03.2015.)

15 Ibidem.

16 Frommerov guide for Croatia, prepared for the US market, says that Trstenica beach in Orebić, is one of the best Croatian beaches. In Best of Croatia section, in the list of beaches, Frommer's has written for Trstenica that it is "civilized beach that isgently lowered into the sea."

17 Pelješac, Wordpress, URL: http://peljesac.wordpress.com/2009/08/13/ plaze-na-peljescu/ (19.03.2015.)
}

The main objective of the study is to determine the extent to which the destination management of Pelješac is responsible for beach management in the function of creation of a competitive tourism product. From the main objective the following research themes have emerged:

- To determine the importance of beaches of Pelješac as a tourist product,

- Identify the purpose, quality and beach equipment,

- Identify the management style of beaches destination management.

The survey questionnaire analyzed socio-demographic characteristics of respondents from which results showed that the majority of respondents were female (75\%). As for the age structure, $50 \%$ of respondents belong to the age group of 41-51 years, followed by the age group 3140 years $(25 \%)$, as well as the age group of $18-30$ years (25\%). Most respondents (75\%) had secondary school education, while $25 \%$ have a college degree.

The Table 5 analyzes data relating to the role of beaches in the tourist offer of a destination. All stakeholders consider that the Pelješac peninsula has the prerequisites for quality tourism development, but that tourism potentials are not fully exploited. All respondents, $100 \%$ of them agree with the fact that the peninsulas dominant product is sun and sea and feel that tourists visiting the beaches of the peninsula of Pelješac increase tourism spending on the peninsula. Namely, if the beach areas are enriched with some additional facilities (sunbeds, showers, beach bars ...), this would increase tourist spending. Three out of four employees of the Tourist Board considered that the attractiveness of the beaches on the peninsula is one of the main factors of attractiveness of the destination. Pelješac Peninsula in its tourist offer also includes cultural - historical resources, and also is known for its vineyards, olive and gastronomy.

Three respondents (TB Ston, TB Trpanj and TZ Orebić) consider that in their municipalities there are beaches that could be touristcly valorised. All of the municipalities on the peninsula have beach resources that could be put into a tourist function. Respondents have further highlighted beaches that should be actively involved in the tourist valorization and should be enriched with new contents: beach Prapratno in Ston, beach Vučine in Žuljana, beaches Divna, Duba i Jezero, and beach Trstenica.

Respondents also singled out beach themes that would be appropriate for the quality development of the beaches on the Pelješac peninsula. The answers are shown the Graph 1.

The chart shows that respondents consider and highlight diving beaches, beaches for families with children, then the dog-friendly beaches, nudist beaches, beaches for surfers, beaches with sports and recreational facilities, romantic beaches or the hotel and eco beaches, and only one beach is considered to be themed as the beach with entertainment for young people, and not a single as adrenaline and urban promenade beach. 
Table 5 The views of stakeholders of the Tourist Board on the importance of beaches in the tourism offer

\begin{tabular}{|c|c|c|}
\hline Description & Yes (\%) & No (\%) \\
\hline Peninsula has the prerequisites for quality tourism development. & $100 \%$ & $0 \%$ \\
\hline Tourism potential of of the Peljesac peninsula is exquisitely used. & $0 \%$ & $100 \%$ \\
\hline The dominant product is on the Pelješac are the sun and the sea. & $100 \%$ & $0 \%$ \\
\hline Beach resources are the most important in the tourist offer of the Pelješac peninsula. & $100 \%$ & $0 \%$ \\
\hline Do you think that the attractiveness of beaches on the peninsula is one of the main factors of tourism offer of Pelješac? & $75 \%$ & $25 \%$ \\
\hline Are there beaches in your municipality that could be a touristcly valorisated? & $75 \%$ & $25 \%$ \\
\hline Do you think that thematizations of beaches would raise the quality of tourist offer of the Pelješac peninsula? & $100 \%$ & $0 \%$ \\
\hline Are beaches in your municipalty managed on the basis on strategic document? & $75 \%$ & $25 \%$ \\
\hline
\end{tabular}

Source: Processing of questionnaires

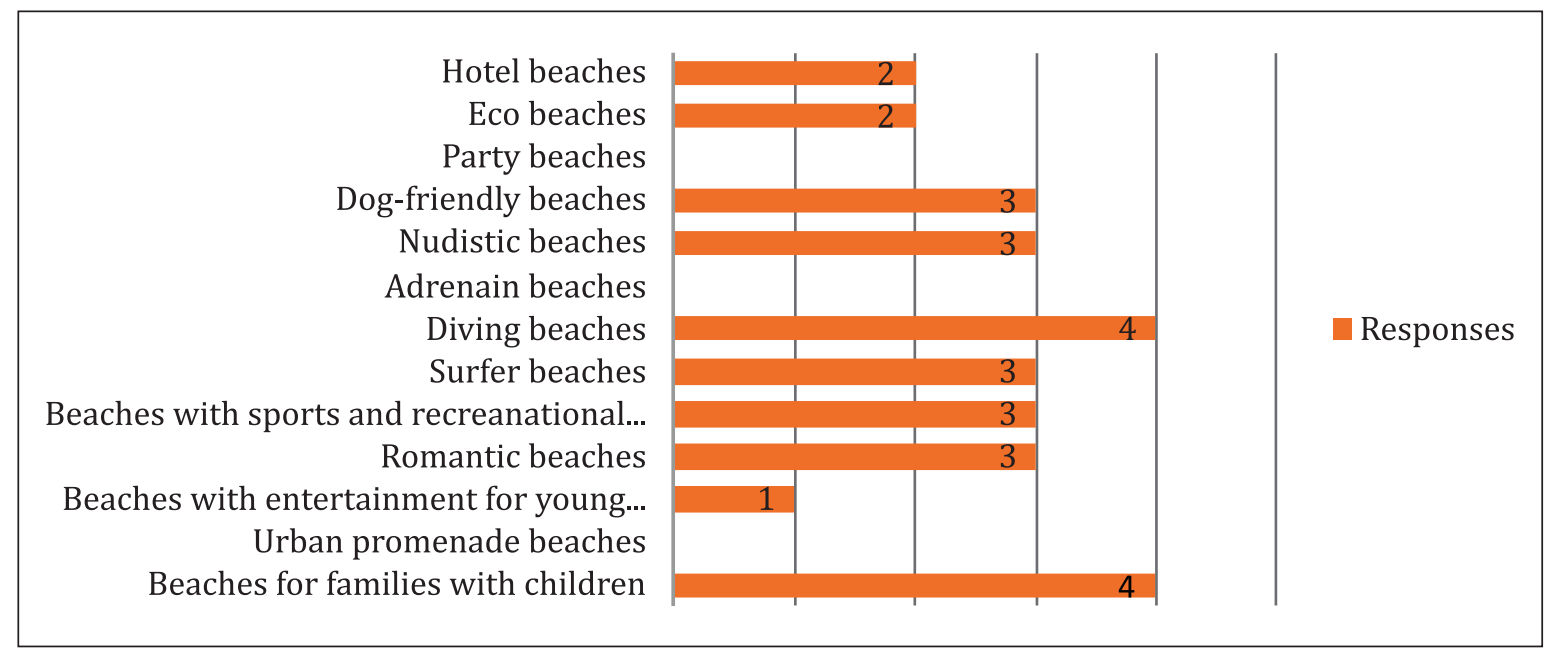

Graph 1 Select beach themes on peninsula

Source: Processing of the author according to the results of their own research

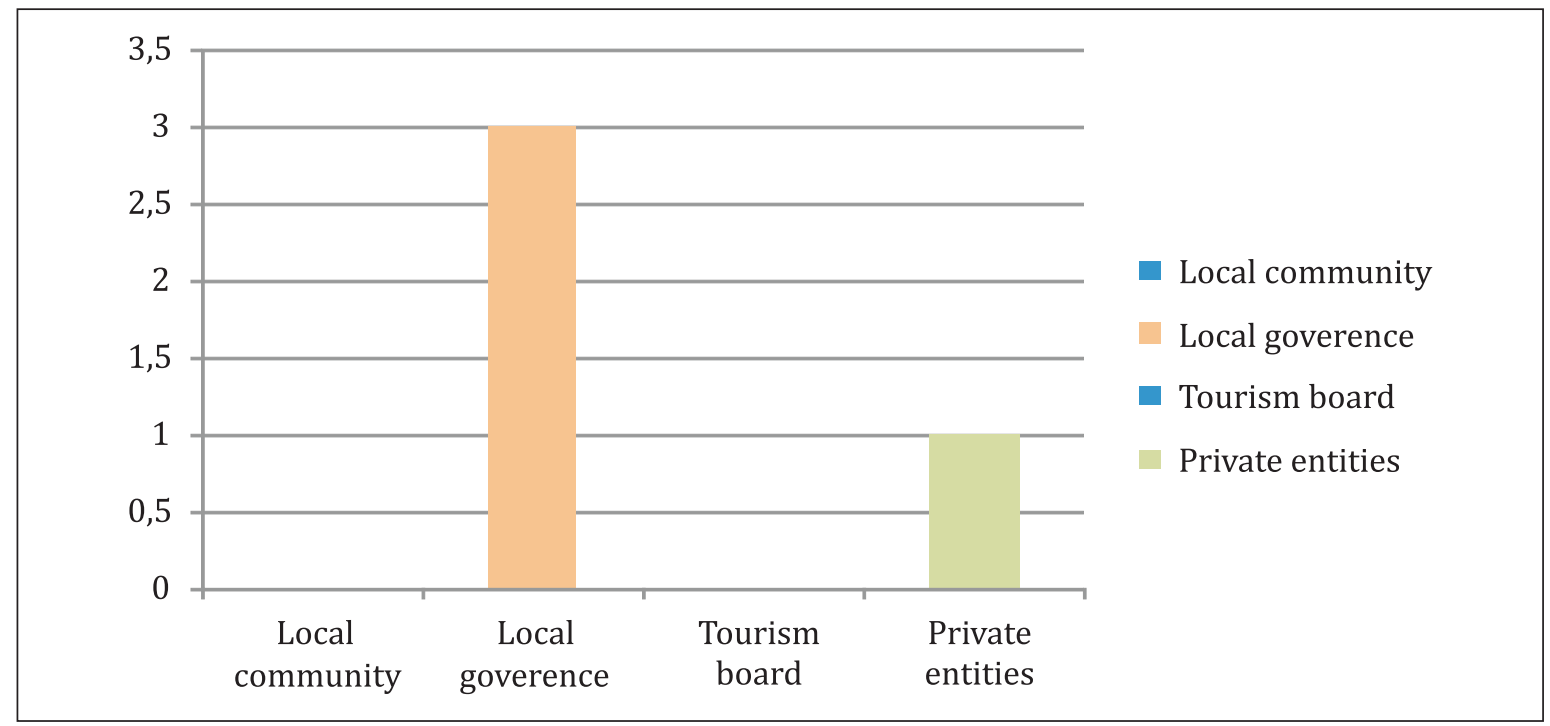

Graph 2 Who in your municipality is participating in decision making on the beaches, in particular on the use of beaches, decoration, equipment, etc.?

Source: Processing of the authors 
Analyzing the views of stakeholders on the management of the beaches, it is clear that three of the stakeholders considered that the local authority/municipality participates in decision making on the beaches, in particular on the use of beaches, decoration, equipment and the like, while one respondent believes that these should be private entities.

To the question: "Is there a document on the management of the beaches in your Tourist Board?" negativly have responded TB Ston, TB Janjina, TB Orebić, and respondent from TB Trpanj considers that that document is there. All the respondents believe that the Pelješac peninsula should have a Strategy for beaches development.

According to the analyzed data it can be concluded that the results are expected, namely, all surveyed employees of tourist boards of Pelješac peninsula considered that there are prerequisites for quality tourism development, and also that this situation is sustainable in the long run, that the beach resources in the tourist offer are extremely important, but that tourism potentials of Pelješac are still not well exploited. Due to the diversity of tourist products offered on the Pelješac peninsula, which in turn can be linked in such a way to form a unique tourist offer, it can be concluded that it is necessary to adopt a strategy of managing the development of tourism in order for beach areas to be optimally exploited, and that an appropriate destination management is necessary in order to ensure implementation of the strategy.

\section{Conclusion}

Beaches are resources that significantly enrich the tourist offer of countries. On the peninsula Pelješac beaches are mostly natural, and only a few of them are arranged in such a way that they had set up showers, cabins, fence and deck chairs and parasols. Peninsula is still promoted primarily as a collection of picturesque 'sun and sea' tourist sites with excellent cuisine. The main carrier of tourism marketing around the area of Pelješac are municipal tourist boards (Orebić, Trpanj, Janjina and Ston). In order for successful differentiation from other large and small spatial-territorial units of Dubrovnik Neretva County, which is also characterized by outstanding picturesque, clean sea and good cuisine, Pelješac and the surrounding areas have to emphasize the uniqueness of tourism experiences that is offered in this area. Beaches should be thematised, because they are diverse and appropriate for adding beach facilities, and so the further development should be based on adding a "personality" to each of them what would make this product tailored to different target segments.

Resources that Pelješac has, its nature, clean sea, "ability" to relax and enchants the, it should be integrated with the traditional values which peninsula has, with the purpose of creating a unique experience by blending the tradition and nature.
Conducted research concluded that beaches as a tourist resource on the Pelješac peninsula are not valorized in a way to suit the modern requirements of the tourist market, because most beaches there ishave no additional content what is the consequence of the lack of appropriate structures, i.e., of destination management managing the beaches.

\section{References}

[1] Cetinski, V.: Strateško upravljanje razvojem turizma i organizacijska dinamika, FTHM Opatija, 2005.

[2] Glamuzina, N.: Pelješac, Naklada Bošković, Split, 2009, p. 60.

[3] Gunn, C.: Tourism Planning, Taylor and Francis, London, New York, 1988.

[4] http://www.orebic-peljesac.eu/hr/txt_plaze-na-peljescu-iu-orebicu.html (14.05.2014.).

[5] Magaš, D.: Destinacijski menadžment - modeli i tehnike, FTHM Opatija, 2008.

[6] Magaš, D.: Management turističke organizacije $i$ destinacije, Sveučilište u Rijeci, Fakultet za turistički i hotelski menadžment u Opatiji, Adamić, Rijeka, 2003.

[7] Nacionalni program upravljanja i uređenja morskih plaža Akcijski plan, Ministarstvo turizma, prosinac 2014.

[8] Operativni priručnik za primjenu modela destinacijske menadžment organizacije (DMO), Glavni ured Hrvatske turističke zajednice, Horwath HTL Zagreb, 2013. http:// business.croatia.hr/Documents/3217/Operativni-prirucnik-za-primjenu-modela-destinacijske-menadzment-organizacije.pdf.

[9] Pelješac, Wordpress, URL: http://peljesac.wordpress.com/ 2009/08/13/plaze-na-peljescu/ (19.03.2015.)

[10] Pilot projekt "1.000 hrvatskih plaža - Jadranske morske zvijezde Kvarnera”, Fakulteta za menadžment u turizmu i ugostiteljstvu, Opatija, 2013.

[11] Plan razvoja turizma Pelješca, URL:http://www.visitorebiccroatia.hr/Content/dokumenti/65_plan\%20razvoja\%20 turizma\%20peljesca.pdf (20.03.2015.)

[12] Pravilnik o vrstama morskih plaža i uvjetima koje moraju zadovoljavati, NN 50/95.

[13] Regionalni program uređenja i upravljanja morskim plažama na području Primorsko-goranske županije, Primorsko-goranska županija, 2015.

[14] Simm, J. D., Beech, N. W., John, S.: A Manual for Beach Management, Proceedings of Conference in Costal Management '95, Putting Policy in to Practice, Institution of Civil Engineers, Bournemouth, Thomas Telford, UK, 1995, pp. 143-162.

[15] Southern Sun-Croatia, URL: http://www.southernsuncroatia.com/cultureandnature/peljesac-nature.asp (19.03.2015.)

[16] Uredba o uređenju i zaštiti zaštićenog obalnog područja mora, NN 128/04, čl. 14: http://www.propisi.hr/print. php?id=1329 (01.05.2015.)

[17] Williams, A., Micaleff, A.: Beach Management: Principle \&Practice, Earth can Publications Ltd., London, UK, 2009.

[18] Zakon o zaštiti okoliša (NN, 76/07, 38/09, 55/11, 90/11, 50/12, 55/12) čl. 53., URL: http://www.zakon. $\mathrm{hr} / \mathrm{z} / 153 / Z a k o n-o-p r o s t o r n o m-u r e \% C 4 \% 91$ enju-i-gradnji (17.03.3015.) 